\title{
QUALITY STANDARD LABELING INFORMATION ON MEAT PACKS DEMANDED BY CONSUMERS AND RELATIONSHIPS WITH PURCHASING MOTIVES
}

\author{
P.H.G.J. De Silva ${ }^{1}$ and A.L. Sandika ${ }^{2}$
}

\begin{abstract}
Worldwide, food-safety crises debates have come forward as an important aspect and apart from all debated food items, meat is accounted at top. Hence, a study was conducted to identify public awareness and adoption toward food certification standards and the factors that associate to Halal, SLS, ISO and HACCP purchase intention of meat. Purposive sampling approach was adopted and data were collected from 100 consumers who purchase meat products for their consumption through pre-tested structured questionnaire by personnel interview. The model explained $R^{2}=0.69$ and $R^{2}=0.61$ of the variability in awareness and adoption, respectively about the factors motivate consumers toward food certificate logo on meat packs. Around $80 \%, 46 \%$ and $30 \%$ of respondents have recorded as high awareness group with regard to SLS, ISO and HACCP standards respectively. Despite that utility of same information always or sometime on purchasing decision reported as low level. A significant relationship was observed for knowledge and utilizes logo of SLS, ISO, Halal and HACCP with socio demographic profiles including religion, gender, net income, education, occupation, interpersonal and mass media.
\end{abstract}

Key words: Certificate standards, Meat packs, Awareness, Adoption

\section{INTRODUCTION}

Globally, diet-related health problems have been under heavy criticism during the last decade (Elizabeth, et al., 1998). Also consumers, producers and governments, as well as scientists from a plethora of disciplines, have recently been involved in debates of numerous food-safety crises. From all debated food items, meat is accounted at top (Richardson, et al., 1994; Issanchou, 1996; Becker, et al., 1998). Therefore, food safety has emerged as an important aspect of consumers' meat purchase decisions (Barendsz, 1998, Andreas, et al., 2006). In order to achieve food safety goal, consumers first be motivated to make use of the food label when they purchasing meat because they may help consumers make healthier food choices and therefore, help to reduce dietrelated diseases. On many occasions consumers ignore label information on food pack due to a lack of awareness. Food quality standards (SLS) and food safety systems (ISO, HACCP) and Halaal certification must be managed throughout the food chain from farm to fork to achieve food safety phenomenon. Therefore, it is very important to study public awareness and adoption towards food quality information. So, research into public awareness and decision-making (adoption) towards quality standards on meat packs is chosen as the showcase to discuss food safety issues from the perspective of the demand side of the consumer. Accordingly, producers can

\footnotetext{
${ }^{I}$ Department of Agricultural Systems, Faculty of Agriculture, University of Rajarata, Puliyankulama, Anuradhapura, Sri Lanka

${ }^{2}$ Department of Agricultural Economics, Faculty of Agriculture, University of Ruhuna, Mapalana, Kamburupitiya
} 
decide whether they should mentioned safety logos on their product or not. Based on this background this study was conducted with the aim of identifying the public awareness and adoption towards food certification standards and factors associated to Halal, SLS, ISO and HACCP purchase intention of meat.

\section{MATERIALS AND METHODS}

This study was focused on consumers who purchase meat products (raw meat, processed meat) for their consumption. Purposively selected 100 consumers were used in order to find out the relevant information such as awareness and adoption to read food quality logos on meat packs. In addition important factors such as gender, age, religion, occupation, income, education, family background, (age, education and income of the family members) information sources (interpersonal and mass media) and enforcement of these information on regarding attributes in food label were also collected. A scale with five levels $(5=$ very high, 4 = high, $3=$ neutral, $2=$ weak, $1=$ very weak) for awareness on SLS, ISO, HACCP, Halaal and 3 levels scale (2 = always $1=$ sometime $0=$ never) was used for determine the adoption SLS, ISO and HACCP, Halaal when purchasing meat products. The Pearson and Kendall's tau-b test was performed to ascertain the relationship between the variables, such as gender, religion, age, education, family background, income, occupation with awareness and adoption to read food quality logos on meat packs. In addition regression model was developed to determine the factors that influence awareness and adoption of certification standards on meat packs.

$Y^{\prime}=\beta_{\mathrm{o}}+\beta_{1} \mathrm{X}_{1}+\beta_{2} \mathrm{X}_{2}+\beta_{3} \mathrm{X}_{3}+\beta_{4} \mathrm{X}_{4}+\beta_{5} \mathrm{X}_{5}$ $+\beta_{6} X_{6}+\beta_{7} X_{7}+\beta_{8} X_{8}+\beta_{9} X_{9}+\beta_{10} X_{10}$ $+\beta_{11} X_{11}+e^{e}$
$\hat{Y}=$ awareness $/$ adoption of consumers towards certification logos on meat packs

$$
\begin{aligned}
& \mathrm{X}_{1}=\text { gender } \\
& \mathrm{X}_{2}=\text { age in years } \\
& \mathrm{X}_{3}=\text { religion } \\
& \mathrm{X}_{4}=\text { occupation } \\
& \mathrm{X}_{5}=\text { income } \\
& \mathrm{X}_{6}=\text { education } \\
& \mathrm{X}_{7}=\text { age of the family members } \\
& \mathrm{X}_{8}=\text { education of the family } \\
& \text { members }_{\mathrm{X}_{9}=\text { net income of the family }} \mathrm{X}_{10}=\text { mass media information } \\
& \mathrm{X}_{11}=\text { interpersonal media información } \\
& \beta_{0}=\text { constan } \\
& \text { é }=\text { error }
\end{aligned}
$$

\section{RESULTS AND DISCUSSION}

The sample comprised of consumers aged between 20 and 59. From the 100 respondents participating, $23 \%$ were male and $77 \%$ females. The $28 \%$ of the respondents had personal monthly income between SLR 36,000 and 45,000 (Table 1). The relevance of safety issues on meat and a better understanding of consumer decision making towards meat purchasing became paramount due to distinct changes at the consumer level. Along with increasing importance of quality issues relating to food safety, human health and wellbeing have gained attention, especially with respect to meat production and consumption. Among the respondents, 90 $\%$ purchased meat and stated that they purchase; raw meat $25.8 \mathrm{~kg}$ and processed meat $2.16 \mathrm{~kg}$, average per annum. There were significant correlations $(\mathrm{P}<0.05)$ between the quantity of meat purchased and the factors such as occupation, gender, religion, income, education, market information sources, income and education of the family members (Table 02). Males tended to buy meat products than females. Results argued that personnel income and their knowledge background significantly motivated for meat products purchasing based on nutritional view. This is an 
expected result because more educated people may be better informed about the nutritional importance of animal protein sources.

Consumer attitudes toward food safety were influenced by consumers' perceived importance of safety measures, information on the labels and consumers' opinion regarding the adequacy on food safety and motivation for food safety regulations (Beniwal and Khetarpal, 2000). Seventy seven percent of the respondents perceived that food safety information on food labels are very important and $72 \%$ expressed that this information helped them on decision making at purchasing of meat products.

Table 01: Demographic statistics of the respondents

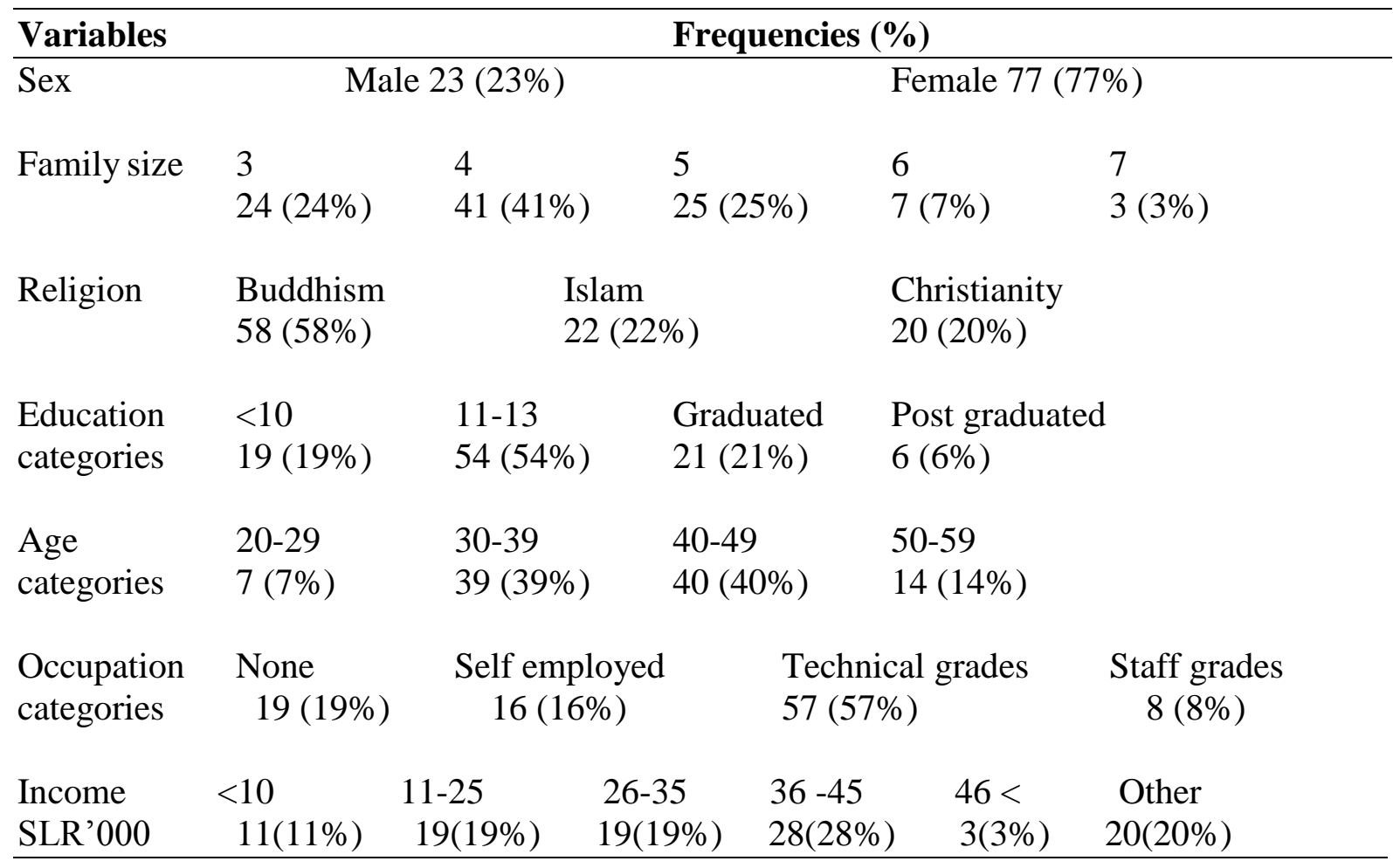

Among the respondents $99 \%, 74 \%, 34 \%$, $34 \%$ and $37 \%$ respectively had obtained marketing information regarding meat products by family members, friends or relatives, neighbors, progressive persons and officers, frequently or occasionally. Respondents claimed that, they get marketing information from mass media such as newspapers $(67 \%)$, radio $(88 \%)$, television $(99 \%)$, farm literature $(40 \%)$ and internet $(19 \%)$ frequently or occasionally. This knowledge may facilitate increasing the efficiency of quality certification standards perceived and thereby decreasing the cost of negatives on expense in health related problems.

Kupiec and Revel, (2001) stated that a "quality attributes" is defined as tangible or intangible product feature which influence quality perception directly upon consumption. Dimara and Skuras, (2003) stated that the importance of certification as extrinsic quality cues varies among consumers and thus the use of such quality cues targets specific segments of the market. Regression analysis was used to analyze the factors that influence the 
awareness and adoption of consumers

towards meat packs.

Table 02: Relationship of demographic variables with the meat purchasing, awareness and adoption to read the food label information

\begin{tabular}{|c|c|c|c|}
\hline & Meat purchasing & Awareness & Adoption \\
\hline Gender & $\begin{array}{l}0.15 \\
(p=0.004)\end{array}$ & $\begin{array}{l}0.26 \\
(p=0.000)\end{array}$ & $\begin{array}{l}0.21 \\
(\mathrm{p}=0.002)\end{array}$ \\
\hline Age (years) & $\begin{array}{l}-0.05 \\
(p=0.58)\end{array}$ & $\begin{array}{l}-0.08 \\
(p=0.39)\end{array}$ & $\begin{array}{l}-0.02 \\
(\mathrm{p}=0.09)\end{array}$ \\
\hline Religion & $\begin{array}{l}0.38 \\
(p=0.000)\end{array}$ & $\begin{array}{l}0.01 \\
(p=0.892)\end{array}$ & $\begin{array}{l}0.004 \\
(\mathrm{p}=0.996)\end{array}$ \\
\hline Occupation & $\begin{array}{l}0.29 \\
(p=0.003)\end{array}$ & $\begin{array}{l}0.21 \\
(p=0.114)\end{array}$ & $\begin{array}{l}0.03 \\
(\mathrm{p}=0.075)\end{array}$ \\
\hline Income & $\begin{array}{l}0.05 \\
(\mathrm{p}=0.002)\end{array}$ & $\begin{array}{l}0.10 \\
(p=0.313)\end{array}$ & $\begin{array}{l}0.06 \\
(\mathrm{p}=0.124)\end{array}$ \\
\hline Education & $\begin{array}{l}0.113 \\
(p=0.011)\end{array}$ & $\begin{array}{l}0.27 \\
(p=0.007)\end{array}$ & $\begin{array}{l}0.26 \\
(\mathrm{p}=0.01)\end{array}$ \\
\hline \multicolumn{4}{|l|}{ Family members } \\
\hline Age & $\begin{array}{l}0.018 \\
(p=0.861)\end{array}$ & $\begin{array}{l}-0.11 \\
(p=0.279)\end{array}$ & $\begin{array}{l}-0.24 \\
(p=0.087)\end{array}$ \\
\hline Education & $\begin{array}{l}0.215 \\
(p=0.032)\end{array}$ & $\begin{array}{l}0.32 \\
(p=0.001)\end{array}$ & $\begin{array}{l}0.62 \\
(p=0.000)\end{array}$ \\
\hline Family income & $\begin{array}{l}0.069 \\
(\mathrm{p}=0.000)\end{array}$ & $\begin{array}{l}0.195 \\
(p=0.057)\end{array}$ & $\begin{array}{l}0.181 \\
(\mathrm{p}=0.071)\end{array}$ \\
\hline \multicolumn{4}{|l|}{ Information source } \\
\hline Mass media & $\begin{array}{l}0.229 \\
(p=0.022)\end{array}$ & $\begin{array}{l}0.51 \\
(p=0.000)\end{array}$ & $\begin{array}{l}0.56 \\
(\mathrm{p}=0.000)\end{array}$ \\
\hline Interpersonal media & $\begin{array}{l}0.275 \\
(p=0.006)\end{array}$ & $\begin{array}{l}0.45 \\
(\mathrm{p}=0.000)\end{array}$ & $\begin{array}{l}0.43 \\
(p=0.000)\end{array}$ \\
\hline
\end{tabular}

Of the twelve variables considered, the explanatory variables accounted for $69 \%$ $\left(\mathrm{R}^{2}=0.69\right)$ and $61 \%\left(\mathrm{R}^{2}=0.61\right)$ of the variability in awareness and adoption, respectively about the factors motivate consumers toward food certificate logo on meat packs. Gender, individual's education, family member's education, interpersonal and mass media affect consumers' total awareness and adoption toward food certificate logo on meat packs (Table 02). The model shows, following equation 1 and 2 for awareness and adoption toward certification standards in meat packs.

Awareness $=3.02 \mathrm{X}_{1}+0.483 \mathrm{X}_{6}+0.12 \mathrm{X}_{9}+$ $2.02 \mathrm{X}_{11}+2.19 \mathrm{X}_{12}+$ é ....(i)

Adoption $=4.16 \mathrm{X}_{1}+0.38 \mathrm{X}_{6}+0.212 \mathrm{X}_{9}+$ $2.46 \mathrm{X}_{11}+3.23 \mathrm{X}_{12}+$ é..... (ii)
Further positive relationship also existed between the level of education and SLS ( $\mathrm{r}=$ $0.59, p=0.003)$, ISO $(r=0.62, p=0.000)$ and HACCP $(r=0.56, p=0.02)$ standards, which motivated consumers to look into the SLS (r $=0.46, \mathrm{p}=0.000)$, ISO $(\mathrm{r}=0.41, \mathrm{p}=0.000)$ and HACCP $(r=0.42, p=0.000)$ logo when they buy meat. Other than that female were more aware about SLS $(r=0.32, p=0.001)$, ISO $(r=0.44, p=0.000)$ and HACCP $(r=$ $0.41, p=0.000)$ than males. This situation was similar for female adoption of SLS ( $\mathrm{r}=$ $0.34, p=0.001)$, ISO $(r=0.30, p=0.002)$ and HACCP $(\mathrm{r}=0.38, \mathrm{p}=0.000)$ when purchasing meat items. Overall, women, especially mothers, with higher levels of education are most likely to read food certificate logos. This may be attributed to the fact that men are generally less interested 
in nutrition and health than women (Nayga, 1999). This argued men are less concerned about food safety issues than women and not concerning food safety when purchasing. And also the relationship between quality expectations and quality experience and its implications for different consumer satisfaction and repeat purchase intent is addressed by Klaus et al (2004). Issanchou, (1996) mentioned the concept of food quality differs from one person to another. As Steenkamp, (1990) pointed out, food quality depends on the perceptions, needs and goals of the consumer.

Respondents were asked to rate themselves of their level of knowledge and adoption about food quality aspects. About half of respondents $(80 \%)$ knew about SLS in meat. Nevertheless only $46 \%$ and $30 \%$ of respondents knew about meat ISO and HACCP. More than half of respondents, claimed to be always or sometime they (61 $\%)$ read SLS logo in meat when they do purchasing. Around $21 \%$ read always or sometime ISO whereas $22.2 \%$ sometime seek HACCP in meat items respectively. ISO and HACCP are the least food quality determining factors among meat purchasing participants, and it was mentioned by participants with the highest level of education only.

SLS, ISO and HACCP standards (hazard analysis and critical control point) cover aspects of hygiene, sanitation and food safety throughout the food manufacturing and food servicing chain. Further, Halal recognized as a new benchmark for safety and quality assurance. Slaughter method is a very important attribute of meat to almost all respondents; however it is significantly more important to meat purchasing behaviour of Muslims. This is an expected result because religion influencing consumers' knowledge and adoption of "Halal". Therefore Muslims buy Halal meat even though brand was not familiar to them. It is an additional requirement for Muslims is that they require food to be Halal because their lives are guided by Islamic Law. Around $34 \%$ respondents seek out Halal logo when they purchase meat. Moreover it is not only seen from the religious viewpoint, Bernues et al., (2003) confirm that young women are strongly in favour of a quality label for Halal meat. Delener, (1994) stated the "Halal" aspect is now undeniably accepted as a quality system worldwide that appeals to both Muslims and non-Muslims as well due to reassurance of the slaughter method and convenience in shopping. Quality standards can be used to transmit important information to consumers on food safety measures (Verbeke and Viaene, 1999). On many occasions consumers ignore the food quality information due to lack of awareness. Grunert, (2002) pointed out quality logos can give consumers another means of inferring experience and credence characteristics of food products. Sanchez et al., (2001) has been reported a positive relationship between the presence of quality standards and aspects related to food safety.

\section{CONCLUSIONS}

Improved knowledge of the relationship between consumers' food selection and socio-demographic factors and consumers' preference of a specific type of information on food labels affect for usage of food certification logos. Based on these producers, distributors, marketing staff and policy makers can pedestal their quality and marketing plans in order to increase consumer confidence toward meat quality and simultaneously increase meat consumption. Therefore implementation of food safety awareness programme is focusing on an information approach referring to meat certificate logos. Consequently, it could be stated that must incorporate to bridge the widening gap between consumer knowledge and actual utility about food safety issues. 


\section{REFERENCES}

Andreas, C. D., Panagiotis, L., and Rodolfo, M. N. J. (2006). Consumers' use of nutritional labels: A review of research studies and issues, Academy of Marketing Science Review, 10, 9, 1-25.

Barendsz, A. W. (1998). Food safety and total quality management, Food Control, 9, 2, 163170

Becker, T., Benner, E., and Glitsch, K. (1998). Summary report on consumer behaviour towar meat in Germany, Ireland, Italy, Spain, Sweden and The United Kingdom - results of a consumer survey, University Hohenheim, Gottingen.

Beniwal, A. and Khetarpal, N. (2000). Impact of nutrition education on knowledge of women consumers regarding food labels, Indian food industry, 19, 4,262-267

Bernues,A.Olaizola, A.and Corcoran,K.(2003). Labelling information demanded by European consumers and relationships with purchasing motives, quality and safety of meat, Meat Sci., 65, 1095-1106.

Delener,N. (1994).Religious contrasts in consumer decision behaviour patterns: their dimensionsand marketing implications, European Journal of Marketing, 28, 5, 36-53.

Dimara, E, and Skuras, D. (2003). Consumer evaluations of product certification, geographic association and tracebility in Greece, European journal of marketing, 37, 5, 690-705

Elizabeth, C, Miller, R.D., Christopher, G., and Maropis, M.D. (1998). Nutrition and dietrelated problems, Clinics in Office Practice, 25, 1, 193-210

Grunert, K. G. (2002). Current issues in the understanding of consumer food choice. Trends in Food Science and Technology, 13, 8, 275-285.

Issanchou, S. (1996), Consumer expectations and perceptions of meat and meat product quality.Meat Science, 43, 5-19.

Klaus, G., G., Lone, B., and Karen, B. (2004), Consumer perception of meat quality and implications for product development in the meat sector-a review, Meat Science, 66, 2, 259-272

Kupiec, B., and Revell, B. (2001). Measuring consumer quality judgments, British food urnal, journal, 103, 1, 7-22

Nayga, R.M. (1999). Towards an understanding of consumers' perceptions of food labels, International Food and Agribusiness Management Review, 2, 1, 29-45

Rodolfo, M. N. J. (1999). Towards an understanding of consumers' perceptions of food labels, International Food and Agribusiness Management Review, 2, 1, 29-45

Richardson, N., MacFie, H., and Shepherd, R. (1994). Consumer attitudes to meat eating, Meat Science, 36 (1/2), 57-65.

Sanchez, M., Sanjuan, A., Akl, G. (2001). The influence of experience in consumption and personal attitude on the purchase of lamb and beef, $71^{\text {st }}$ Seminar of European Association of Agricultural Economics, The food consumer in the early 21 st century, Zaragoza, Spain.

Steenkamp, J. B. (1990). Conceptual model of the quality perception process, J Bus Res, 21, 309-333.

Verbeke, W, Viaene, J. (1999).Consumer attitude to beef quality labeling and associations with beef quality labels, J Int Food Agribusiness Marketing 10, 3, 45-65. 